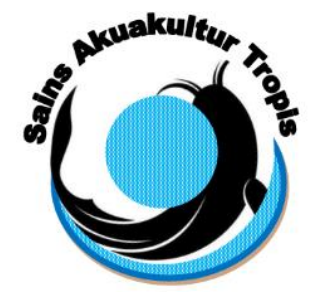

\author{
Jurnal Sains Akuakultur Tropis \\ Departemen Akuakultur \\ Fakultas Perikanan dan IImu Kelautan - Universitas Diponegoro \\ JI. Prof. Soedarto, SH, Tembalang, Semarang 50275 \\ Telp. (024) 7474698, Fax.: (024) 7474698 \\ Email: sainsakuakulturtropis@gmail.com, sainsakuakulturtropis@undip.ac.id
}

\title{
PERFORMA EFISIENSI PEMANFAATAN PAKAN DAN PERTUMBUHAN \\ LELE SANGKURIANG YANG DIBUDIDAYA DI DESA TAMBAKSARI, KECAMATAN ROWOSARI, KABUPATEN KENDAL MELALUI PENAMBAHAN ENZIM PAPAIN DALAM PAKAN BUATAN
}

\author{
Efficiency Performance of Feed Utilization and Growth of Sangkuriang Catfish Cultivated in Tambaksari \\ Village, Rowosari, Kendal through the Addition of Papain Enzymes in Artificial Feed
}

\author{
Diana Rachmawati *), Istiyanto Samidjan, Johannes Hutabarat, \\ Seto Windarto, Ristiawan Agung Nugroho \\ Departemen Akuakultur, \\ Fakultas Perikanan dan Ilmu Kelautan, \\ Jl. Prof. Soedarto, SH, Tembalang, Semarang, Jawa Tengah -50275, Telp/Fax. +62247474698 \\ *) Corresponding author: dianarachmawati1964@gmail.com
}

\begin{abstract}
ABSTRAK
Salah satu faktor penting dalam pemeliharaan lele sangkuriang (Clarias sp) adalah pakan. Biaya pakan dihitung sekitar 60-70\% dari total biaya dalam satu siklus produksi. Tingginya porsi biaya pakan disebabkan oleh ketidakefisienan pakan. Salah satu solusi untuk mengatasi masalah tersebut adalah dengan menambahkan enzim papain dalam pakan. Tujuan dari penelitian ini adalah untuk menguji pengaruh suplementasi enzim papain dalam pakan terhadap pertumbuhan dan tingkat kelangsungan hidup lele sangkuriang (Clarias sp) yang dipelihara di kolam, di Desa Tambaksari, Kecamatan Rowosari, Kabupaten Kendal, Provinsi Jawa Tengah, Indonesia. Bibit lele sangkuriang yang digunakan memiliki berat rata-rata 2,23 $\pm 0,56 \mathrm{~g} /$ benih. Penelitian ini menggunakan metode eksperimental dengan Rancangan Acak Lengkap. Percobaan dilakukan dalam 4 (empat) perlakuan dan setiap perlakuan memiliki 4 (empat) pengulangan. Perlakuan terdiri dari penambahan enzim papain protease ke dalam pakan dengan dosis $0 \mathrm{mg} / \mathrm{kg}$ pakan (A), 0,75 mg / kg pakan (B), 1,5 mg / kg pakan (C) dan 2, $25 \mathrm{mg} / \mathrm{kg}$ pakan (D). Hasil penelitian menunjukkan bahwa suplemen enzim papain dalam pakan secara signifikan $(\mathrm{P}<0,01)$ memengaruhi Specific Growth Rate (SGR); dan tidak berpengaruh signifikan (P>0,05) Survival Rate (SR) lele sangkuriang (Clarias $\mathrm{sp}$ ). Dosis terbaik penambahan enzim papain adalah pada level $1,5 \mathrm{mg} / \mathrm{kg}$ pakan (perlakuan C) yang memiliki efek optimal pada pertumbuhan ikan. Parameter kualitas air masih dalam kisaran layak untuk membudidayakan lele sangkuriang (Clarias sp).
\end{abstract}

Kata kunci: Suplementasi, enzim papain, pakan, lele sangkuriang

\section{ABSTRACT}

One of important factors in rearing Sangkuriang Catfish (Clarias sp) is feed. The cost of feed was accounted for about $60-70 \%$ of total cost in one production cycle. The high portion of feed cost was due to inefficiency of the feed. One of the solutions to solve the problem was by adding papain enzyme in the feed. The objective of the study was to examine the effects of papain enzyme supplementation in the feed on growth and survival rate of Sangkuriang Catfish (Clarias sp) that were raised in pond, at the Tambaksari Village, Rowosari District, Kendal Regency, Central Java Province, Indonesia. The Sangkuriang catfish fingerlings were used in the study with the average weight of 2,23 $\pm 0,56 \mathrm{~g} /$ fingerling. The study used experimental method with Completely Random Design. The experiment was conducted in 4 (four) treatments and each treatment had 4 (four) repetitions. The treatments were by adding papain protease enzyme into the feed with the doses of $0 \mathrm{mg} / \mathrm{kg}$ feed (treatment A), $0,75 \mathrm{mg} / \mathrm{kg}$ feed (treatment B), 1,5 $\mathrm{mg} / \mathrm{kg}$ feed (treatment C) and 2,25 $\mathrm{mg} / \mathrm{kg}$ pakan (treatment D). The results showed that the supplementation of papain enzyme in the feed significantly $(P<0,01)$ influenced Specific Growth Rate (SGR); otherwise, it insignificantly $(P>0,05)$ influenced the Survival Rate (SR) of Sangkuriang Catfish 
(Clarias sp). The best dose of the addition of papain enzyme was at the level of 1,5 $\mathrm{mg} / \mathrm{kg}$ feed (treatment C) which has optimal effect on the growth the fish. The parameters of water quality was still in viable range to cultivate Sangkuriang Catfish (Clarias sp).

Keywords: supplementation, papain enzyme, feed, Sangkuriang catfish

Article Received: 07-07-2019; Accepted: 12-09-2019

\section{PENDAHULUAN}

Ikan lele sangkuriang (Clarias sp) adalah salah satu ikan air tawar yang banyak dibudidayakan dan dikonsumsi di Indonesia. Ikan ini banyak dikonsumsi karena mudah diolah, banyak disukai, dan memiliki kandungan protein yang tinggi. Selain itu, ikan ini juga dibudidayakan karena memiliki waktu pertumbuhan yang relatif cepat. Tingginya permintaan konsumen membuat petani lele melakukan usaha yang intensif. Keberhasilan budidaya lele Sangkuriang sangat ditentukan oleh keberdaan pakan. Permasalahan yang dihadapi pembudidaya lele Sangkuriang adalah efisiensi pakan yang belum optimal dari pakan yang diberikan selama kegiatan budidaya dan biaya pakan sekitar 40-60\% dari total biaya produksi (Olmos et al., 2011).

Patil dan Singh (2014) menyatakan bahwa efisiensi pakan dapat ditingkatkan dengan penambahan enzim eksogenus diantaranya enzim papain. Lebih lanjut Dawood et al. (2014), melaporkan bahwa enzim eksogenous dapat menambah penyerapan nutrisi pakan. Penambahan enzim eksogenus membantu pemecahan protein nabati sangat dianjurkan untuk meningkatkan laju pertumbuhan ikan. Amri dan Mamboya, (2012) menyatakan enzim papain adalah enzim proteolitik yang mampu memecah protein menjadi asam amino sehingga lebih mudah dicerna.

Beberapa penelitian penambahan enzim papain pada pakan telah dilaporkan oleh Patil dan Singh (2014) bahwa penambahan enzim papain $0,1 \mathrm{mg}$ dalam pakan memberikan pertumbuhan terbaik Macrobrachium rosenbergii. Selanjutnya Khati et al. (2015) melaporkan penambahan enzim papain dosis $10 \mathrm{~g} / \mathrm{kg}$ pakan papain memberikan pertumbuhan dan protein efisiensi ratio terbaik fingerling Labeo rohita. Lebih lanjut Muchlisin et al. (2016) menyatakan bahwa penambahan enzim papain $27,5 \mathrm{mg} / \mathrm{kg}$ pakan memberikan pertumbuhan terbaik ikan keureling (ukuran 0,30 g dan 3,5 cm). Dari hasil penelitian yang telah dilaporkan oleh peneliti sebelumnya bahwa kebutuhan enzim papain berbeda untuk setiap spesies dan ukuran. Penelitian ini bertujuan mengkaji pengaruh pertumbuhan benih lele sangkuriang yang dibudidaya di Desa Tambaksari, Kecamatan Rowosari, Kabupaten Kendal.

\section{MATERI DAN METODE}

Penelitian ini dilaksanakan di kawasan kampung lele Desa Tambaksari, Kecamatan Rowosari, Kabupaten Kendal. Ikan uji yang digunakan dalam penelitian ini adalah benih lele Sangkuriang dengan bobot rata-rata $3,53 \pm 0,38 \mathrm{~g}$ /ekor dengan padat penebaran sebesar 75 ekor/m2 yang dibudidaya dikolam tanah. Adaptasi benih lele Sangkuriang dilakukan sampai ikan dapat menyesuaikan diri dengan lingkungan yang baru dan terbiasa dengan pakan buatan yang diberikan selama satu minggu. Pemuasaan benih lele Sangkuriang selama satu hari dilakukan sebelum penelitian yang bertujuan untuk menetralkan sisa-sisa metabolisme pakan sebelumnya, sehingga pada awal perlakuan didapatkan bobot awal yang akurat dan tidak terpengaruh sisa-sisa metabolisme pakan sebelumnya. Pemberian pakan dilakukan secara at satiation dengan pemberian pakan tiga kali sehari. Sampling untuk mengetahui pertambahan bobot lele Sangkuriang dilakukan seminggu sekali selama 60 hari.

Wadah pemeliharaan yang digunakan dalam penelitian ini adalah kolam tanah dengan ukuran 6 x 10 meter2 sebanyak 3 kolam tanah. Masing-masing kolam tanah dibagi menjadi empat petakan sebagai wadah budidaya. Penempatan petakan dilakukan secara acak di dalam kolam tanah. Pakan uji berupa pakan buatan bentuk pellet kandungan protein $30 \%$ (SNI, 2000) ditambahkan enzim papain dengan cara spray sesuai perlakuan, yaitu A $(0$ $\mathrm{mg} / \mathrm{kg}$ pakan), B (0,75 mg/kg pakan), C (1,5 mg/kg pakan) dan D (2,25 mg/kg pakan). Dosis enzim papain dalam penelitian ini modifikasi hasil penelitian Singh et al. (2011), menyatakan dosis enzim papain $2 \mathrm{mg} / \mathrm{kg}$ pakan merupakan dosis terbaik pertumbuhan ikan mas (Cyprinus carpio).

Penelitian ini menggunakan metode eksperimen, Rancangan Acak lengkap (RAL), 4 perlakuan dan masingmasing perlakuan diulang sebanyak 4 kali. Parameter yang diamati meliputi total konsumsi pakan (TKP), laju pertumbuhan relatif (RGR), efisiensi pemanfaatan pakan (EPP), protein efisiensi ratio (PER) dan kelulushidupan (SR) digunakan sebagai parameter yang dievaluasi. Data yang diperoleh dianalisa dengan analisis ragam (ANOVA). Apabila hasil analisis ragam berpengaruh nyata $(\mathrm{P}<0,05)$ atau berpengaruh sangat nyata $(\mathrm{P}<0,01)$ maka dilakukan uji wilayah ganda Duncan untuk mengetahui perbedaan nilai tengah antara perlakuan (Steel et al., 1996). Parameter kualitas air meliputi suhu, oksigen terlarut (DO), pH dilakukan setiap hari dan pengukuran amonia (NH3) dilakukan pada awal dan akhir pemeliharaan. Data kualitas air dianalisis secara deskriptif. 
Perlakuan dalam penelitian ini adalah:

A : Dosis enzim papain $0 \mathrm{mg} / \mathrm{kg}$ pakan

B : Dosis enzim papain $0,75 \mathrm{mg} / \mathrm{kg}$ pakan

C : Dosis enzim papain $1,5 \mathrm{mg} / \mathrm{kg}$ pakan

D : Dosis enzim papain $2,25 \mathrm{mg} / \mathrm{kg}$ pakan

Parameter yang diamati dengan rumus sebagai berikut:

\section{Total Konsumsi Pakan}

Total konsumsi pakan dihitung dengan menggunakan rumus Tacon (1987) sebagai berikut:

$$
\mathrm{TKP}=\mathrm{F} 1-\mathrm{F} 2
$$

keterangan:

$\begin{array}{ll}\mathrm{TKP} & =\text { Tingkat konsumsi pakan } \\ \mathrm{F} 1 & =\text { Jumlah pakan awal }(\mathrm{g}) \\ \mathrm{F} 2 & =\text { Jumlah pakan sisa }(\mathrm{g})\end{array}$

\section{Efisiensi Pemanfaatan Pakan}

Nilai efisiensi pemanfaatan pakan (EPP) dapat ditentukan dengan rumus Tacon (1987) sebagai berikut:

$$
\mathrm{EPP}=\frac{\mathrm{Wt}-\mathrm{Wo}_{\mathrm{O}}}{\mathrm{F}} \times 100 \%
$$

keterangan:

EPP = Efisiensi pemanfaatan pakan (\%)

Wt $=$ Bobot total ikan pada akhir penelitian $(\mathrm{g})$

Wo = Bobot total ikan pada awal penelitian $(\mathrm{g})$

$\mathrm{F} \quad$ = Jumlah pakan yang dikonsumsi selama penelitian $(\mathrm{g})$

\section{Protein Efisiensi Ratio} berikut:

Nilai protein efisiensi ratio (PER) dapat ditentukan dengan menggunakan rumus Tacon (1987) sebagai

$$
\mathrm{PER}=\frac{\mathrm{Wt}-\mathrm{Wo}_{\mathrm{O}}}{\mathrm{Pi}} \times 100 \%
$$

keterangan:

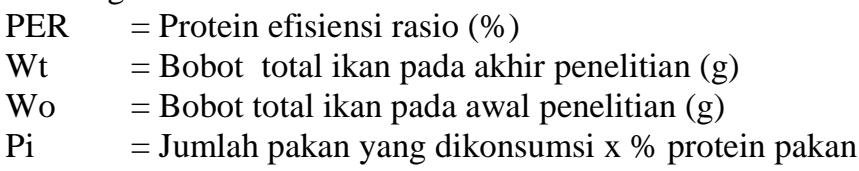

\section{Laju Pertumbuhan Relatif}

Menurut Takeuchi (1988) laju pertumbuhan relatif atau relative growth rate (RGR) ikan dihitung menggunakan rumus sebagai berikut:

$$
\mathrm{RGR}=\frac{\mathrm{Wt}-\mathrm{Wo}_{0}}{\mathrm{Wo} \times \mathrm{t}} \times 100 \%
$$

$$
\begin{aligned}
& \text { keterangan: } \\
& \begin{array}{ll}
\mathrm{RGR} & =\text { Laju pertumbuhan relatif }(\% \text { per hari) } \\
\mathrm{Wt} & =\text { Bobot total ikan pada akhir pemeliharaan }(\mathrm{g}) \\
\mathrm{Wo} & =\text { Bobot total ikan pada awal pemeliharaan }(\mathrm{g}) \\
\mathrm{t} & =\text { Waktu pemeliharaan (hari) }
\end{array}
\end{aligned}
$$

\section{Kelulushidupan}

Kelulushidupan atau survival rate (SR) dihitung untuk mengetahui tingkat kematian kematian ikan uji selama penelitian, kelulushidupan dapat dihitung berdasarkan rumus Takeuchi (1988):

$$
\mathrm{SR}=\frac{\mathrm{Nt}}{\mathrm{N} 0} \times 100 \mathrm{mg}
$$

keterangan:

$\begin{array}{ll}\mathrm{SR} & =\text { Kelulushidupan ikan }(\%) \\ \mathrm{Nt} & =\text { Jumlah ikan pada akhir penelitian (ekor) } \\ \mathrm{N} 0 & =\text { Jumlah ikan padaawal penelitian (ekor) }\end{array}$


Analisis data yang dilakukan meliputi nilai tingkat konsumsi pakan (TKP), efisiensi pemanfaatan pakan (EPP), protein efisiensi ratio (PER), laju pertumbuhan relatif (RGR), kelulushidupan (SR), dan kualitas air. Variabel yang didapatkan kemudian dianalisis menggunakan analisis sidik ragam (ANOVA) selang kepercayaan 95\% dan $99 \%$ untuk mengetahui pengaruh perlakuan terhadap parameter yang diamati. Jika hasil ANOVA berpengaruh nyata $(\mathrm{P}<0,05)$ dan sangat nyata $(\mathrm{P}<0,01)$ dilanjutkan dengan Uji Wilayah Ganda Duncan untuk menentukan selisih antar nilai tengah. Data kualitas air dianalisis secara deskriptif.

\section{HASIL DAN PEMBAHASAN}

Data pengamatan parameter TKP, PER, EPP, SGR dan SR benih lele Sangkuriang (Clarias sp. var. sangkuriang) selama penelitian dapat dilihat pada Tabel 1 dan data perameter kualitas air dapat dilihat Tabel 2.

Tabel 1. Nilai Rata-rata TKP, EPP, PER, RGR, dan SR pada Lele Sangkuriang Selama Pemeliharaan

\begin{tabular}{cccccc}
\hline \multirow{2}{*}{ Perlakuan } & \multicolumn{5}{c}{ Variabel yang diamati } \\
\cline { 2 - 6 } & TKP $(\mathrm{g})$ & EPP $(\%)$ & PER $(\%)$ & RGR $(\% /$ hari $)$ & SR $(\%)$ \\
\hline A & $213.10 \pm 2.24^{\mathrm{a}}$ & $55,19 \pm 1,87^{\mathrm{b}}$ & $1,17 \pm 0,12^{\mathrm{b}}$ & $2,23 \pm 4,87^{\mathrm{b}}$ & $88,67 \pm 3,64^{\mathrm{a}}$ \\
B & $251.21 \pm 3.69^{\mathrm{a}}$ & $56,43 \pm 1,62^{\mathrm{b}}$ & $1,64 \pm 0,09^{\mathrm{b}}$ & $2,42 \pm 0,48^{\mathrm{b}}$ & $90,08 \pm 3,00^{\mathrm{a}}$ \\
C & $261,62 \pm 4,30^{\mathrm{a}}$ & $72,82 \pm 1,04^{\mathrm{a}}$ & $2,51 \pm 0,07^{\mathrm{a}}$ & $3,97 \pm 0,19^{\mathrm{a}}$ & $91,57 \pm 3,77^{\mathrm{a}}$ \\
D & $260,14 \pm 4,15^{\mathrm{a}}$ & $60,51 \pm 1,38^{\mathrm{b}}$ & $1,44 \pm 0,03^{\mathrm{b}}$ & $2,79 \pm 0,14^{\mathrm{b}}$ & $88,33 \pm 3,89^{\mathrm{a}}$ \\
\hline
\end{tabular}

Keterangan: Huruf superskrip yang berbeda menunjukkan perbedaan yang nyata $(\mathrm{P}<0.01)$

Tabel 2. Data kualitas air media budidaya lele Sangkuriang selama penelitian

\begin{tabular}{|c|c|c|c|c|c|}
\hline \multirow{2}{*}{$\begin{array}{l}\text { Kualitas } \\
\text { Air }\end{array}$} & \multicolumn{4}{|c|}{ Perlakuan } & \multirow[t]{2}{*}{ Kelayakan } \\
\hline & A & B & $\mathrm{C}$ & $\mathrm{D}$ & \\
\hline$\left({ }^{\circ} \mathrm{C}\right)$ & $25,4-30,2$ & $26,8-30,0$ & $26,6-30,8$ & $25,7-30,2$ & $25-30 *$ \\
\hline \multirow[t]{2}{*}{$(\mathrm{mg} / \mathrm{L})$} & $4,52-4,75$ & $4,55-4,96$ & $4,53-4,75$ & $4,43-4,77$ & $3-5 *$ \\
\hline & $7,0-7,2$ & $7,0-7,6$ & $7,2-7,8$ & $7,4-7,5$ & $6,5-8^{*}$ \\
\hline onia (mg/L) & $0,064-0,084$ & $0,064-0,084$ & $0,064-0,084$ & $0,064-0,084$ & $<0,1 *$ \\
\hline
\end{tabular}

Amonia $(\mathrm{mg} / \mathrm{L})$

Hasil pengamatan parameter kualitas air budidaya lele Sangkuriang selama penelitian (Tabel 2) apabila dibandingkan dengan kisaran kelayakan menurut pustaka masih dalam kisaran yang layak untuk kegiatan budidaya lele Sangkuriang.

Hasil penelitian menunjukkan bahwa penambahan eksogen enzim papain dalam pakan buatan memberikan pengaruh sangat nyata $(\mathrm{P}<0,01)$ terhadap EPP, PER dan SGR dan tidak berpengaruh nyata $(\mathrm{P}>0,05)$ terhadap TKP dan SR lele Sangkuriang. Hasil analisis ragam menunjukan bahwa pemberian pakan buatan dengan suplementasi enzim papain pada lele Sangkuriang tidak berpengaruh nyata terhadap total konsumsi pakan lele Sangkuriang. Hal ini diduga karena tidak terdapat perbedaan kandungan nutrisi pada pakan yang signifikan antar perlakuan. Berdasarkan hasil analisis proksimat pakan, kandungan protein tidak jauh berbeda pada semua pakan perlakuan, begitu pula lemak, bahan ekstrak tanpa nitrogen (BETN) dan serat kasar. Kandungan nutrisi pada pakan yang cukup baik diduga mempengaruhi palatabilitas pakan dan tingkat pengambilan pakan oleh ikan. Sedangkan pengambilan pakan yang rendah oleh ikan dapat dipengaruhi oleh adanya bahan yang sulit dicerna ikan, adanya zat anti nutrisi serta adanya bahan yang sulit dikonsumsi ikan ikan (Obirikorang et al., 2015).

Nilai total konsumsi pakan berturut-turut dari yang tertinggi yaitu perlakuan $\mathrm{C}(1,5 \mathrm{mg} / \mathrm{kg}$ pakan $)$ sebesar $261,62 \pm 4,30 \mathrm{~g}$, perlakuan B $(0,75 \mathrm{mg} / \mathrm{kg}$ pakan $)$ sebesar $251,21 \pm 3,69 \mathrm{~g}$, perlakuan D $(2,25 \mathrm{mg} / \mathrm{kg}$ pakan $)$ sebesar

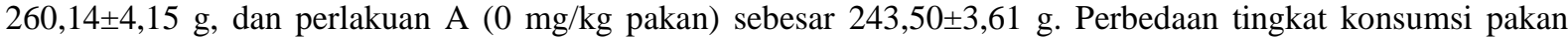
diduga disebabkan karena perbedaan nafsu makan pada lele Sangkuriang. Besar kecilnya total konsumsi pakan pada ikan dipengaruhi oleh beberapa faktor, antara lain sifat fisik pakan misalnya bau, rasa, ukuran, dan warna (Abidin et al., (2015).

Nilai efisiensi pemanfaatan pakan tertinggi terdapat pada perlakuan C $(1,5 \mathrm{mg} / \mathrm{kg}$ pakan $)$ sebesar $72,82 \pm 1,04 \%$. Hal ini diduga karena penambahan enzim papain pada pakan buatan mampu menghidrolisis rantai polipeptida menjadi asam amino sehingga pakan lebih mudah dicerna dan terserap baik pada lele Sangkuriang. Disamping itu enzim papain diduga juga dapat membantu proses pencernaan pakan yang diberikan sehingga energi dalam pakan dapat memenuhi kebutuhan perbaikan jaringan tubuh, aktivitas ikan dan juga pertumbuhan. Semakin banyak nutrisi dalam pakan yang terhidrolisis dan mudah terserap dalam tubuh ikan maka akan semakin tinggi nilai efisiensi pemanfaatan pakan pada lele Sangkuriang. Hal ini diperkuat oleh pendapat Singh et al. (2011), menyatakan bahwa papain adalah enzim protease yang menghidrolisis protein menjadi peptida dan merupakan 
faktor kunci untuk menambah pencernaan protein, penyerapan yang cepat dan membantu meningkatkan pertumbuhan. Hal ini menunjukkan bahwa penambahan enzim papain dapat meningkatkan daya cerna pakan dan selanjuntya mempengaruhi efisiensi pemanfaatan pakan oleh ikan. Menurut Patil dan Singh (2014), enzim proteolitik memainkan peranan penting dalam proses pencernaan protein. Enzim proteolitik mengubah protein dalam pakan yang masuk ke dalam tubuh menjadi peptida sederhana dan asam amino sehingga bisa diserap oleh tubuh. Peningkatan daya cerna pakan yang mengandung enzim papain dikarenakan sudah tersedianya enzim proteolitik dalam pakan yang mampu membantu proses hidrolisis protein dalam pencernaan ikan. Disamping itu nilai EPP pada setiap perlakuan dengan penambahan enzim papain dinyatakan cukup baik karena memiliki nilai diatas 50\%. Hal ini sesuai dengan pernyataan Craig dan Helfrich (2002) bahwa pakan dapat dikatakan baik bila nilai efisiensi pakan lebih dari $50 \%$ atau bahkan mendekati $100 \%$.

Nilai efisiensi pemanfaatan pada perlakuan A ( $0 \mathrm{mg} / \mathrm{kg}$ pakan) tidak berbeda nyata dengan B $(0,75 \mathrm{mg} / \mathrm{kg}$ pakan) dan D (2,25 mg/kg pakan). Hal ini diduga enzim papain dalam pakan A (0 mg/kg pakan) dan B $(0,75 \mathrm{mg} / \mathrm{kg}$ pakan) memiliki dosis lebih rendah dari pakan C (1,5 mg/kg pakan) sehingg enzim papain tidak berkerja maksimal dalam menghidrolis protein rantai polipeptida menjadi asam amino rantai monopeptida. Sedangkan pada perlakuan $\mathrm{D}(2,25 \mathrm{mg} / \mathrm{kg}$ pakan) merupakan dosis lebih besar dari $1,5 \mathrm{mg} / \mathrm{kg}$ pakan (C) menyebabkan penurunan aktivitas enzim papain dikarena jumlah enzim papain pada perlakuan tersebut melebihi dosis yang efektif untuk kerja enzim papain, dengan dimikian kondisi tersebut dapat menghambat metabolisme pada lele Sangkuriang.

Peningkatan dosis enzim papain belum tentu memberikan hasil EPP yang tinggi, hal itu dikarenakan enzim memiliki kadar optimum. Hal itu berkaitan dengan mekanisme kerja enzim. Mekanisme pengaruh ini secara tidak langsung dijelaskan oleh Khattak et al. (2006) bahwa enzim mengkatalis secara spesifik dan bertindak pada satu substrat. Pernyataan tersebut menyimpulkan bahwa ketika tidak tersedia substrat untuk enzim, maka tidak ada aktivitas enzim. Hal ini terjadi pada perlakuan yang penambahan enzimnya berlebihan namun substratnya terbatas. Penambahan enzim secara berlebihan dengan substrat terbatas tidak dapat meningkatkan aktivitas enzim, karena aktivitas enzim terhenti saat substrat habis. Hal ini sependapat dengan Adugna et al. (2004), meningkatkan konsentrasi subtrat dapat meningkatkan aktivitas enzim sampai batas maksimum tercapai. Kondisi tersebut menunjukkan bahwa molekul substrat dan molekul enzim akan bergabung pada sisi aktif sampai semua sisi aktif terpakai, pada keadaan tersebut enzim dikatakan dalam keadaan maksimum.

Nilai rasio efisiensi protein tertinggi dalam penelitian ini terdapat pada perlakuan $\mathrm{C}$ dengan penambahan

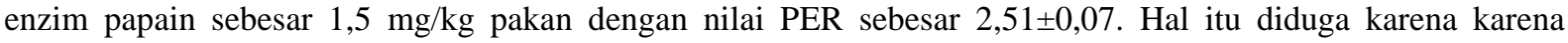
perlakuan $\mathrm{C}$ mengandung dosis yang tepat untuk lele Sangkuriang. Enzim protease berperan dalam proses pemecahan protein pakan yang akan meningkatkan nilai PER, yang secara langsung akan mempengaruhi pertumbuhan. Hal ini sesuai dengan pendapat Singh et al. (2011) yang menyatakan bahwa pakan yang ditambah enzim papain menghasilkan daya cerna protein yang lebih tinggi jika dibandingkan dengan pakan tanpa penambahan enzim papain, hal ini karena penambahan enzim papain dapat meningkatkan kandungan protein dan enzim protease yang berasal dari pakan. Menurut Khati et al. (2015), enzim papain adalah enzim protease yang menghidrolisis protein, yang merupakan faktor kunci untuk meningkatkan daya cerna protein dan penyerapannya, yang pada akhirnya mempengaruhi pertumbuhan. Enzim papain bertindak sebagai katalis biologis yang dapat meningkatkan daya cerna pakan kualitas rendah, sehingga biaya pakan dapat ditekan. Enzim papain dapat mengurangi faktor negatif dari asam fitat yang berasal dari bahan dasar nabati pakan.

Hasil uji wilayah ganda Duncan perlakuan A (0 mg/kg pakan), B (0,75 mg/kg pakan) dan D (2,25 mg/kg

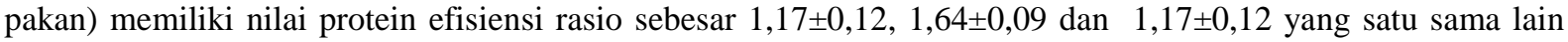
tidak berbeda nyata, hal tersebut diduga karena dosis enzim papain pada perlakuan A ( $0 \mathrm{mg} / \mathrm{kg}$ pakan $)$ dan B $(0,75$ $\mathrm{mg} / \mathrm{kg}$ pakan) masih dibawah dosis yang efektif seperti pada perlakuan C (1,5 $\mathrm{mg} / \mathrm{kg}$ pakan) untuk kerja enzim papain, selanjutnya untuk perlakuan $\mathrm{D}(2,25 \mathrm{mg} / \mathrm{kg}$ pakan) merupakan dosis yang melebihi dosis efektif untuk enzim papain dalam menghidrolisa protein menjadi asam amino untuk membentuk protein tubuh lele Sangkuriang. Dampak negatif penambahan enzim protease yang melebihi kebutuhan ikan diungkapkan oleh Infantea dan Cahua (2007) yang menyatakan bahwa jika penambahan protein hasil hidrolisis berlebihan dapat berdampak negatif pada pertumbuhan dan kelangsungan hidup larva, hal ini diduga karena kandungan yang terlalu tinggi mempengaruhi regulasi sintesis dan sekresi tripsin. Hal ini juga terjadi pada penambahan enzim xilanase yang berlebihan.

Hasil analisis ragam menunjukan bahwa penambahan enzim papain dalam pakan berpengaruh sangat nyata $(\mathrm{P}<0,01)$ terhadap laju pertumbuhan relative lele Sangkuriang. Berdasarkan hasil penelitian laju pertumbuhan relatif lele Sangkuriang menghasilkan nilai tertinggi pada perlakuan $\mathrm{C}$ dengan penambahan enzim papain sebanyak

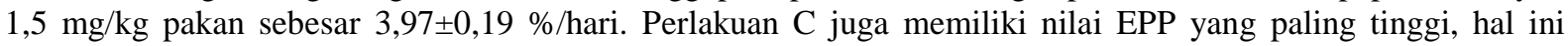
menunjukkan bahwa nilai RGR berbanding lurus dengan nilai EPP. Sehingga semakin tinggi nilai EPP maka semakin tinggi pula nilai RGR. Hal ini sesuai dengan pernyataan Huet (1970), nilai EPP yang tinggi berkaitan dengan laju pertumbuhan yang tinggi. Nilai EPP yang tinggi menunjukkan bahwa sedikit zat makanan yang dirombak untuk memenuhi kebutuhan energi dan selebihnya untuk pertumbuhan.

Perlakuan enzim papain pada pakan menghasilkan laju pertumbuhan berturut-turut yakni perlakuan $\mathrm{C}(1,5$

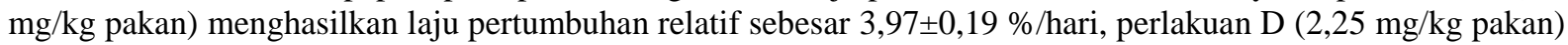

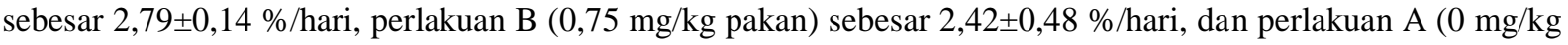


pakan) sebesar 2,23 $\pm 0,87 \%$ /hari. Pertumbuhan ini terjadi karena energi yang terdapat dalam pakan melebihi kebutuhan energi untuk maintenance. Nilai laju pertumbuhan relatif pada ikan dipengaruhi oleh tingkat pemanfaatan pakan oleh tubuh ikan. Penambahan enzim papain dalam penelitian ini mampu meningkatkan tingkat pemanfaatan pakan oleh lele Sangkuriang. Penambahan enzim papain mampu mengoptimalkan proses pencernaan protein dalam pakan. Nutrisi dalam pakan yang dicerna dengan maksimal akan menghasilkan energi yang dapat diserap dan diedarkan ke seluruh tubuh dan dimanfaatkan oleh lele Sangkuriang.

Hasil uji wilayah ganda Duncan perlakuan A, B dan D memiliki nilai laju pertumbuhan relatif tidak berbeda nyata, hal tersebut diduga karena dosis enzim papain pada perlakuan A ( $0 \mathrm{mg} / \mathrm{kg}$ pakan $)$ dan B $(0,75 \mathrm{mg} / \mathrm{kg}$ pakan $)$ masih dibawah dosis yang efektif pada perlakuan $\mathrm{C}(1,5 \mathrm{mg} / \mathrm{kg}$ pakan) untuk kerja enzim papain, selanjutnya untuk perlakuan $\mathrm{D}(2,25 \mathrm{mg} / \mathrm{kg}$ pakan) merupakan dosis yang melebihi dosis efektif untuk enzim papain dalam menghidrolisa protein menjadi asam amino untuk membentuk protein tubuh lele Sangkuriang. Hal ini didukung oleh penyataan Infantea dan Cahua (2007) jika penambahan protein hasil hidrolisis berlebihan dapat berdampak negatif pada pertumbuhan dan kelangsungan hidup larva, hal ini diduga karena kandungan yang terlalu tinggi mempengaruhi regulasi sintesis dan sekresi tripsin. Hal ini juga terjadi pada penambahan enzim xilanase yang berlebihan. Lebih lanjut Kazerani dan Shahsavani (2011) mengemukakan enzim dengan dosis berlebihan dapat membebaskan monosakarida secara berlebihan dan mendorong terjadinya hiperglikemia yang dapat menghambat pertumbuhan.

Hasil Analisis ragam menunjukkan bahwa penambahan enzim papain pada pakan buatan tidak berpengaruh nyata $(\mathrm{P}>0,05)$ terhadap kelulushidupan lele Sangkuriang, hal ini diduga bahwa pakan dengan penambahan enzim papain memberikan pengaruh pada pertumbuhan, akan tetapi tidak memberikan pengaruh nyata terhadap tingkat kelulushidupan. Hal ini didukung oleh Dabrowski dan Glogowski (1977) yang menyatakan bahwa enzim proteolitik tidak berpengaruh terhadap kelulushidupan organisme yang dibudidayakan.

\section{KESIMPULAN DAN SARAN \\ Kesimpulan}

Kesimpulan yang didapat dari penelitian ini bahwa:

1. Suplementasi enzim papain pada pakan buatan untuk lele Sangkuriang meningkatkan pertumbuhan lele Sangkuriang yang dibudidaya oleh pembudidya lele Sangkuriang di desa Tambaksari, Kecamatan Rowosari, Kabupaten Kendal.

2. Dosis terbaik suplementasi enzim papain terhadap pertumbuhan lele Sangkuriang sebesar $1,5 \mathrm{mg} / \mathrm{kg}$ pakan (perlakuan C).

\section{Saran}

Saran yang dapat diberikan dari penelitian ini yaitu:

1. Suplementasi enzim papain sebesar $1,5 \mathrm{mg} / \mathrm{kg}$ pakan pada pakan buatan dapat digunakan untuk meningkatkan pertumbuhan lele Sangkuriang.

2. Disarankan melakukan penelitian lanjut tentang penambahan eksogen enzim pencernaan dalam pakan buatan pada lele Sangkuriang pada calon induk lele Sangkuriang.

\section{UCAPAN TERIMA KASIH}

Terima kasih penulis ucapkan kepada Ketua Lembaga Penelitian Pengabdian Masyarakat (LPPM) UNDIP yang telah memberi dana penelitian dari Sumber Dana Selain APNBP Universitas Diponegoro Tahun Anggaran 2019, No: 386-05/UN.7.P4.3/PM/2018, tanggal 30 April 2019.

\section{DAFTAR PUSTAKA}

Abidin, Z., M. Junaidi, Paryono, N. Cokrowati, S. Yuniarti. 2015. Pertumbuhan dan konsumsi pakan ikan lele (Clarias sp.) yang diberi pakan berbahan baku local. Jurnal Ilmu Ilmu Periran, Pesisir, dan Periknan, 4(1): 33-39. ISSN 2089-7790.

Adugna, S., L.A.M. Alemu, T. Kelemu, H. Tekola, B. Kibret and S. Genet. 2004. Medical Biochemistry. Gondar University; Jimma University and Debub University, In collaboration with the Ethiopia Public Health Training Initiative; The Carter Center; The Ethiopia Ministry of Health, and The Ethiopia Ministry of Education, 264 p.

Amri, E. dan F. Mamboya. 2012. Papain, a Plant Enzyme of Biological Importance: A Review. American Journal of Biochemistry and Biotechnology., 8(2):99-104

Boyd, C. E., 1982. Water quality management for pond fish culture. cod. Water quality management for pond fish culture., Amsterdam: Elsevier Scientific Publishing Co., 318 p., ISBN: 0444420541.

Craig. S and L. A. Helfrich. 2002. Understanding Fish Nutrition, Feeds and Feeding. Cooperative Extension

Dawood, M.A.O., A.E. Dakar, M. Mohsen, E. Abdelraouf, S. Koshio, M. Ishikawa and S. Yokoyama. 2014. Effects of Using Exogenous Digestive Enzymes or Natural Enhancer Mixture on Growth, Feed Utilization, and Body Composition of Rabbitfish, Siganus rivulatus. J.Agri. Sci. \& Tech. 8(4): 180 187. 
Dabrowski K, Glogowski K, 1977 A study of application of proteolytic enzymes to fish food. Aquaculture, 12: 249-360

Huet, M. 1970. Texbook of Fish Culture. Fishing News (Book Ltd.), London, 436 p.

Infantea, J.L.Z. and C.L. Cahua. 2007. Dietary Modulation of Some Digestive Enzymes and Metabolic Processes in Developing Marine Fish: Applications to Diet Formulation. Aquaculture, 268: 1-14.

Kazerani, H.R. and Shahsavani. 2011. The Effect of Supplementation of Feed with Exogenous Enzymes on the Growth of Common Carp (Cyprinus carpio). Iranian Journal of Veterinary Research, 12 (2): 127-137.

Khati, A., M. Danish, K. S. Mehta dan N. Pandey. 2015. Estimation of Growth Parameters in Fingerlings of Labeo rohita (Hamilton, 1822) Fed with Exogenous Nutrizyme in Tarai Region of Uttarakhand, India. African Journal of Agricultural Research. 10(30), pp. 3000 - 3007.

Khattak, F.M., T.N. Pasha, Z. Hayat and A. Mahmud. 2006. Enzymes in Poultry Nutrition. Joernal Anim. Pl. Sci, 16:1-2.

Muchlisin, Z. A., F. Afrido, T. Murda, N. Fadli, A. A. Muhammadar, Z. Jalil dan C. Yulvizar. 2016. The Effectiveness of Experimental Diet with Varying Levels of Papain on The Growth Performance, Survival Rate and Feed Utilization of Keureling Fish (Tor tambra). Biosaintifika, 8(2): 172-177.

Obikiorang, K.A., S. Amisaha, S.C. Fialor, P.V. Skov. 2015. Effects of Dietary Inclusions of Oilseed Meals on Physical Characteristics and Feed Intake of Diets for the Nile Tilapia, Oreochromis niloticus. Aquaculture Reports, 1:43-49.

Olmos, J., Leonel Ochoa, Jesus Paniagua-Michel and Rosalia Contreras. 2011. Functional Feed Assessment on Litopenaeus vannamei Using 100\% Fish Meal Replacement by Soybean Meal, High Levels of Complex Carbohydrates and Bacillus Probiotic Strains. Journal Marine Drugs, 9, 1119-1132

Patil, D. W., dan H. Singh. 2014. Effect Of Papain Supplemented Diet On Growth And Survival Of Post-Larvae of Macrobrachium rosenbergii. Internasional Journal of Fisheries and Aquatic Studies. 1(6) : 176-179. Service Publication. Virginia State University, USA.

Singh, P., S. Maqsood, M. H. Samoon, V. Phulia, M. Danish, dan R. S. Chalal. 2011. Exogenoush Supplementation of Papain as Growth Promoter in Diet of Fingerlings of Cyprinus carpio. Faculty of Fisheries, Shere-eKashmir University of Agricultural Science and Technology of Kashmir, India. 3:1-9 pp.

Standar Nasional Indonesia (SNI). 2000. Produksi Induk Ikan Lele Dumbo (C. gariepinus x C. fuscus) Kelas Induk Pokok (Parent Stock). 01-6484.3.

Steel R.G.D., J.H. Torrie \& D.A. Dickey, 1996 Principles and Procedures of Statistics: A Biometrical Approach. 3rd Edition, McGraw Hill, Inc. Book Co., New York, 352-358.

Tacon, A. E. J. 1987. The Nutrition and Feeding Formed Fish and Shrimp a Training Manual Food and Agriculture of United Nation Brazilling, Brazil. 108 p.

Takeuchi, T. 1988. Laboratory Work Chemical Evaluation of Dietary Nutrient, p. 179 - 232. In: T. Watanabe (ed): Fish Nutrition and Mariculture. Kanagawa Fisheries Training Center, Japan Internasional Cooperation Agency, Tokyo. 